\title{
Changes in endogenous gibberellin-like substances in onion bulbs (Allium cepa L.) cv. Sochaczewska during storage
}

\author{
ELŻBIETA KIELAK, MARIA BIELINSKA - CZARNECKA
}

Laboratory of Plant Physiology, Institute of Biology, Agricultural and Teacher University, Prusa 12, 08-110 Siedlce, Poland

(Received: February 22, 1989)

A bstract

Onions cv. Sochaczewska were dried up under an umbrella roof till October 15 th or till November 15 th and thereafter stored in a cold room at $0-1^{\circ} \mathrm{C}$ until May 15 th. During 4 -year of experiment gibberellin activity was determined each month during storage. Three periods of high activity of gibberellins were found in most cases: in December, in February-March and in late spring. In general, onions dried longer (till November $15 \mathrm{th}$ ), showed lower gibberellin activity than onions dried shorter. Gibberellin-like substances under investigation are localized in almost all $\mathrm{Rf}$ zones of chromatogram. Sprouting and rooting was related to gibberellin activity.

\section{INTRODUCTION}

Changes in endogenous gibberellin-like substances activity is closely connected with successive development phases of onion plants. Low level of gibberellins activity was reported at the end of onions dormancy i.e. at the beginning of their growth (K a t o, 1966b; N o o d e n, 1969; I s e n be r g and T ho m a s, 1970). Very low activity of gibberellins was observed by $\mathrm{T} \mathrm{h} \mathrm{o} \mathrm{m} \mathrm{a} \mathrm{s} \mathrm{(1969)} \mathrm{in} \mathrm{onion}$ extracts showing internal symptoms of sprouting, whereas, high level of gibberellins was observed in onion bulbs with growing onion leaves. These results suggest that the increase of gibberellin level was mainly a consequence of shoot elongation and was not primarily causal.

Two peaks of gibberellin activity were found in onion bulbs during storage by Th om as (1969), I s e n berg and Thom as (1970) and Thom as and I s e $n$ b e r $g$ (1972). The first seems to be connected with vernalization, the second with organ development and rapid spring growth. 


\section{MATERIAL AND METHODS}

Experiments were performed in two variants: the onions were dried up under an umbrella roof: I - till October 15 th and II - till November 15th at the ambient temperature. Thereafter onion bulbs from both variants were stored in a cold room at $0-1^{\circ} \mathrm{C}$ until May 15 th. The sampling was repeated every month. At each sampling hormones were extracted from the plugs $1.5 \mathrm{~cm}$ in diameter which were taken from the center of the bulbs with a base plate.

$25 \mathrm{~g}$ of fresh material was homogenized and extracted twice with $96 \%$ ethanol. The combined ethanol fractions were evaporated in vacum at $40^{\circ} \mathrm{C}$ and thereafter the water residue was fractioned according to the method of $\mathrm{H}$ a y a $\mathrm{s} \mathrm{i}$ and $\mathrm{R} \mathrm{a} \mathrm{p} \mathrm{pa-}$ p o r t (1966) with modification of B i a 1 e $\mathrm{k}$ (1974). Neutral and acidic fractions of the extracts after evaporation to dryness were disolved in ethanol and put TLC-plates (Kisielgel 60F-254). Separation occurred in a mixture of ethyl acetate-chloroform-formic acid (50:50:1) by ascending chromatography. The chromatograms were divided into $1 \mathrm{~cm}$ wide sections and eluted twice with $10 \mathrm{~cm}^{3}$ mixture of ethyl acetate and ethanol $1: 1 / \mathrm{v} / \mathrm{v} /$. Thereafter the eluates from the chromatogram scctions were evaporated to dryness. Neutral and acidic fractions of the extracts were bioassayed by dwarf pea test (M c C o m b and Ca r r, 1958) with modifications of B i a le $\mathrm{k}$ (1974). The eluates from the chromatogram sections were dissolved in $1.5 \mathrm{~cm}^{3} 0.05 \%$ "Tween 20 " and were dropped on pea seedlings twice: first time $20 \mu \mathrm{l}$ per plant after the first day of seedling growth and $30 \mu \mathrm{l}$ per plant after the second day.

\section{RESULTS AND DISCUSSION}

Two fractions of gibberellins: neutral and acidic were found in all onion bulb extracts during storage. It confirms the results of many authors investigating Allium ccpa L. and other bulbons plants (A ung and De Hertog h, 1968; A ung and Peters on, 1974; S yrtanova and Rakhimbajev, 1983). We noted higher activity of acid gibberellins than the neutral ones in the majority of research dates. However, we did not observe the decrease of neutral gibberellin fractions accompanied by an increase of acid gibberellin fractions during storage, which was observed for example by $\mathrm{Rakhimbaje} \mathrm{v}$ and O ls a n s kaja (1976) as well as S y r $\mathrm{t}$ a $\mathrm{n} \mathrm{ova}$ and $\mathrm{R}$ a k h i m ba je v (1983). Generally the activity of neutral and acid fractions changed parallelly. For this reason we present the sum of neutral and acid gibberellins. Changes in the sum of endogenous gibberellin-like substances in onions during storage period are shown in Figs. 1-4. We have found that three periods (peaks) of higher activity characterize changes in endogenous gibberellins in the majority of cases (Figs. 1, 2, 4). The first peak was noted in December, the second in February or March. The first two peaks generally agree with those found by Th o mas (1970), Evans (1971), Thomas and I s e n berg (1972) and 
I s e $\mathrm{n}$ b e $\mathrm{r} g$ et al. (1974). High activity of gibberellins was also observed in our experiments at the end of onions storage i.e. in April or May. This third peak was more or less visible in each year. The changes of gibbercllins activity observed in the season 1981/82 (Fig. 3) werc somewhat different from those in the remaining seasons: the first peak of activity occurred earlier i.e. in October or November. In this year the changes of inhibitors and cytokinins were also not typical (see $\mathrm{K} \mathrm{i} \mathrm{e} \mathrm{l} \mathrm{a} \mathrm{k}$ et al., 1988 and in press). Supposedly it was related to weather conditions during the onion vegetation. In this year, June, July and also October and November were very wet.

Our four-year investigations showed marked changes in GA activity during storage. Three peaks occurred in all years, generally in similar periods. As it was mentioned in this respect our results coincide well with those of $\mathrm{T} \mathrm{ho} \mathrm{m}$ a $\mathrm{s}$ and I s e $n$ b e $r g$ (1972). These results concern, however, only one season. They worked with other cultivares ( $L$ a n c a s t e $r$ and $R$ i j s b u r g e r). High activity of gibberellin in late spring observed in our investigations, was also observed in $\mathrm{T} h \mathrm{~h} \mathrm{~m}$ a $\mathrm{s}$ and I s e n b e r g (1972) graphs, however, they not discern this activity as a special peak. It seems therefore that the occurrence of two or three peaks of gibberellins activity may be quite common in bulbons plants. I s e $n$ b e $r g$ et al. (1974) suggest that the first peak is connected with vernalization (or more exactly, probably, with the end of vernalization). E v a n s (1971) in his review cited reports of rapid rises in endogenous gibberellins in several species during vernalization. The second flush was associated with organ development and rapid spring growth. These authors, however, give no explanation why there is a very low activity between these two peaks. On the other hand it seems that sprout formation proceeds during January (i.e. the time of GA-activity depression) without any visible interruption. In the paper of Th o m a s and I s e n be r g (1972) this January-depression between two peaks is also very distinct. After $\mathrm{K}$ a r s s e $\mathrm{n}$ and $\mathrm{L} \mathrm{a} \mathrm{c} \mathrm{k} \mathrm{a} \mathrm{(1985)} \mathrm{the} \mathrm{GA} \mathrm{requirement} \mathrm{of}$ germination depended on the degree of dormancy which, in turn, was determined by the level of ABA during development.

The gibberellin-like substances in our investigation were localized in almost all Rf-zones of chromatograms. It may indicate a large number of endogenous gibberellins in onions (Allium cepa L.). It agrees with the results of A u $\mathrm{ng}$ and D e $\mathrm{He} \mathrm{r}$ to $g \mathrm{~h}(1967,1968)$ and A u $\mathrm{g}$ et al. (1986). They determined gibberellins GA1, GA3, GA5, GA13 in bulbons plants.

We showed, that the length of onion drying under the umbrella roof influences the level of endogenous gibberellins. In most cases, onions dried longer, i.e. to mid. November, showed lower gibberellins activity than onions dried shorter, i.e. to mid. October. Probably during for a longer period with simultaneous gradual precooling of onions before placing in to a cold room was connected with a decrease of gibberellin activity.

Our research also allows to notice a negative dependence between the level of gibberellins and the ability to rooting and sprouting (in room temperature). This was noticable particularly at the beginning of onior, storage. For instance, in onions dried shorter in season 1981/82 when a high level of gibberellins was observed - in October 
and in onions dried longer - in November, we noted a high percentage of onions with roots (Fig. 3, tab. 1). In season 1982/83 in December, when the level of gibberellins was very high, we noted high percentage of onion (Fig. 4, tab. 2).

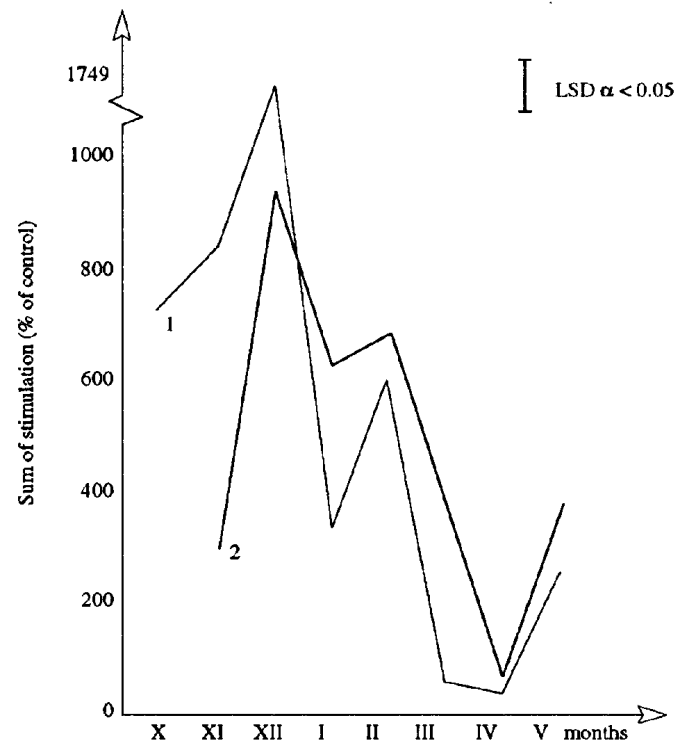

Fig. 1. Changes of endogenous gibberellin-like substances in onion in season 1979/1980 1-Drying to 15 October, 2 - Drying to 15 November

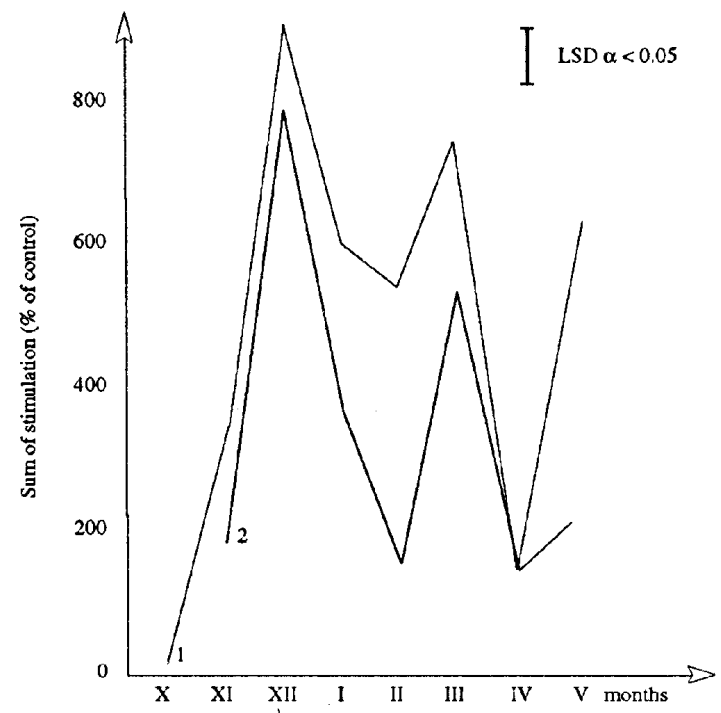

Fig. 2. Changes of endogenous gibberellin-like substances in onion in season 1980/1981 As in Fig. 1. 


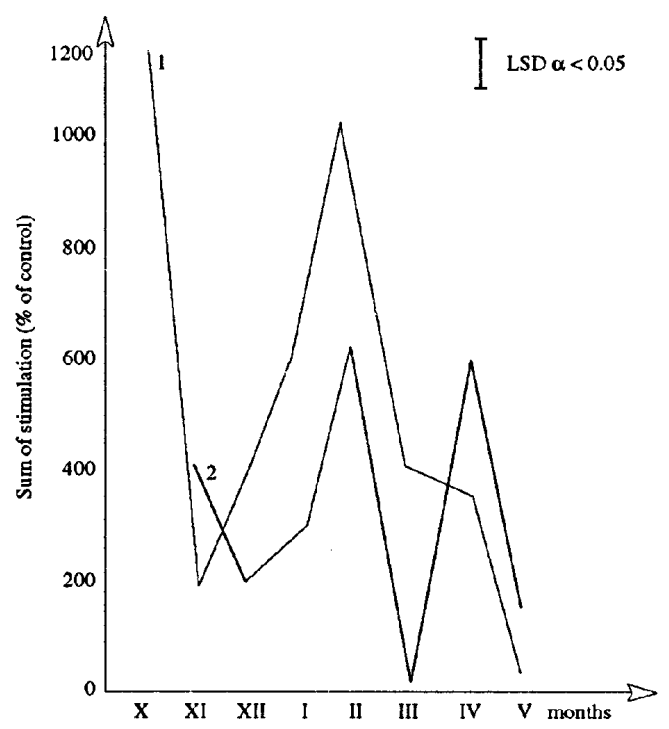

Fig. 3. Changes of endogenous gibberellin-like substances in onion in season 1981/1982 As in Fig. 1.

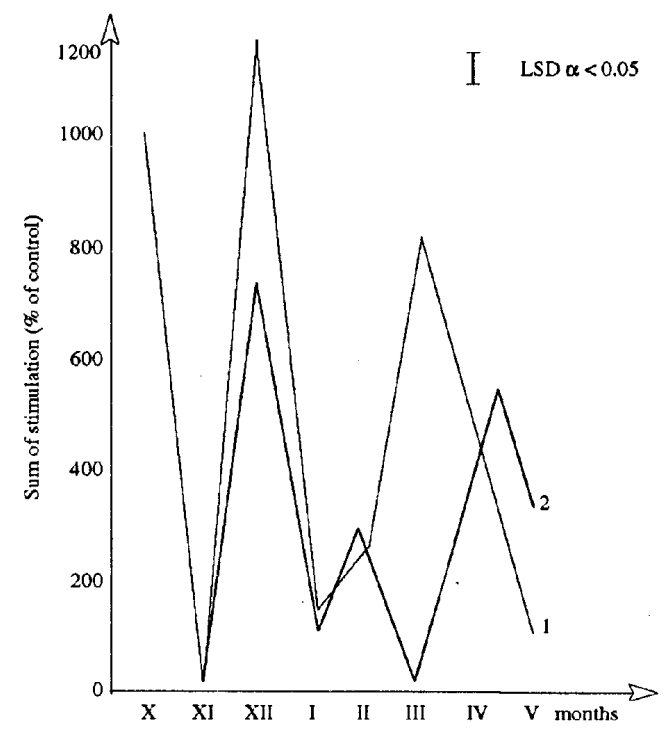

Fig. 4. Changes of endogenous gibberellin-like substances in onion in season 1982/1983 As in Fig. 1. 
Table 1

Percentage of onions with roots in season 1981/82

\begin{tabular}{|l|cc|}
\hline \multirow{2}{*}{ Season } & \multicolumn{2}{|c|}{$1981 / 82$} \\
\cline { 2 - 3 } & \multicolumn{2}{|c|}{ Percentage of onions with roots } \\
\hline Onion dried & After 5 days & After 10 days \\
to 15 October & 45 & 65 \\
to 15 November & 55 & 70 \\
\hline
\end{tabular}

Table 2

Percentage of onions with inside leaves in season 1982/83

\begin{tabular}{|l|c|}
\hline \multirow{2}{*}{ Season } & $1982 / 83$ \\
\cline { 2 - 2 } & Percentage of onions with inside leaves \\
\hline Onion dried & After 10 days \\
to 15 October & 93 \\
to 15 November & 84 \\
\hline
\end{tabular}

\section{REFERENCES}

A ung L. H., De Hertog h A.A., 1967. The occurrence of gibberellin-like substances in tulip bulbs (Tulipa sp.). Plant Cell Physiol. 8: 201-205.

A u n g L. H., De He r tog h A. A., 1968. Gibberellin-like substances in non-cold and cold-treated tulip bulbs. [In]: Biochemistry and Physiology of Plant Growth Substances. F. Withtman and G. Setterfield. eds. Runge Press, Ottawa, Canada: 943-956.

A ung L. H., De Hertog h A. A., Stab y G., 1968. Temperature regulation of endogenous gibberellin activity and development of Tulipa gesneriana L. Plant Physiol. 44: 403-406.

$\Lambda \mathrm{u} n \mathrm{~g} \mathrm{~L}$ L. H., P e te r s o n C. E., 1974. Gibberellin-like substances of dormant and non-dormant bulbs of Allium cepa L. J. Amer. Soc. Hort. Sci. 99: 279-281.

B i a e k K., 1974. A preliminary study of activity of gibberellin-like substances in potato tubers. Z. Pflanzenphysiol. 71: 370-372.

E v a n s L.T., 1971. Flower induction and the florigen concept. Ann. Rev. Plant Physiol. 22: 365-387.

$\mathrm{H}$ a y a s h i F., R a p p a p or $\mathrm{t} \mathrm{L}$., 1966. Isolation, crystallization and partial identification of potato factor II from potato tubers. Plant Physiol. 41: 53-58.

I s e n b e r g F. M. R., Th o m a s T. H., 1970. Onion dormancy. Ann. Rpt. Nat. Veg. Res. Sta., Wellesbourne, Warwick, 72-73.

Is enberg F. M. R., Thomas T. H., Pendergras s M., Abdel-Rahman M., 1974. Hormone and histological differences between normal and maleic hydrazide treatment onions stored over winter. Acta Hort. 38: 95-125.

Kars se n C. M., L a c k a E., 1985. A revision of the hormone balance theory of seed dormancy: studies on gibberellin and/or abscisic acid-deficient mutants of Arabidopsis thaliana. [In]: Plant growth substances 1985: 315-323.

K a to T., 1966b. Physiological studies on the bulbing and dormancy of onion plants. VIII. Relations between dormancy and organic constituents of bulbs. J. Jap. Soc. Hort. Sci. 35: 142-151.

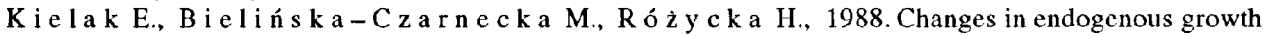
inhibitors in onion bulbs (Allium cepa L.) cv. Sochaczewska during storage. Acta Agrobotanica 41:265-274.

M c C o m b A.J., Car r D. J., 1958. Evidence from a dwarf pea bioassay for naturally occurring gibberellins in the growing plant. Nature 181: 1548-1549. 
N o o d e n L. D., 1969. The mode of action of maleic hydrazide: inhibition of growth. Physiol. Plant.22: $260-270$.

R a k h i m b a j e v I. R., O 1 s a $\mathbf{n} s \mathrm{ka}$ a R. V., 1976. Dinamika endogennych gibberellinov v processe perechoda lukovic cesnoka ot sostojanija pokoja k aktivnomu rostu. Fizjologija Rast. 23(1): 76-80.

$S$ y $r$ a $n$ ow a G. A., R a $k$ h i m b a j e v I. R., 1983. Fitogormony i pokoj lukovicnych rastienij. Nauka, Alma-Ata: 6-90.

Th o m a s T. H., 1969. The role of growh substances in the regulation of onion bulb dormancy. J. Exp. Bot. 20: 124-137.

Th o m a s T. H., I s e n b e r g F. M. R., 1972. Hormone physiology of onion bulbs during dormancy. Exper. Hortic. 23: 48-51.

Ts u k a moto Y., Fu j it a M., In a ba T., A s a h ir a T., 1969. Changes of growth promoting substances and abscisic acid during the dormancy in onion. Memoris of the Research Institute for Food Science, Kyoto University. 30: 24-37.

\title{
Zmiany endogennych substancji giberelinopodobnych w cebuli (Allium cepa L.) odm. Sochaczewska podczas przechowywania
}

\author{
Streszczenie
}

Cebulę odmiany Sochaczewska dosuszano pod wiatą do 15 października lub do 15 listopada, a następnie przechowywano $w$ komorze chlodniczej o temperaturze $0-1^{\circ} \mathrm{C}$ do 15 maja. Oznaczenia giberelin byly wykony wane co miesiąc, w ciągu 4-ch sezonów przechowalniczych.

Wykazano trzy okresy wysokiej aktywności giberelin: w grudniu, w okresie luty-marzec i późną wiosną. W większości przypadków cebula dosuszana dłużej charakteryzowała się wyższą aktywnością giberelin, niż cebula dosuszana krócej.

Oznaczane substancje giberelinopodobne lokalizowały się prawie we wszystkich $\mathrm{Rf}$ chromatogramu. Wyrastanie korzeni i szczypioru bylo związane $\mathrm{z}$ występowaniem zwiększonej aktywności giberelin. 